\title{
Renal elimination of amiodarone and its desethyl metabolite
}

\author{
L. HARRIS* \\ M.B., M.R.C.P. \\ W. J. MCKENNA \\ M.D.
}

S. J. KRIKLER

\author{
C. R. K. HIND \\ M.B., M.R.C.P. \\ C. SAVAGE \\ M.B., M.R.C.P. \\ G. C. A. STOREY
}

\begin{abstract}
D. W. HOLT $\ddagger$
Ph.D.
\end{abstract}

The Division of Cardiovascular Disease, Department of Medicine, Royal Postgraduate Medical School, Londidn W12 OHS and $\ddagger$ Poisons Unit, Guy’s Hospital, London SE1 9RT

\begin{abstract}
Summary
Two patients in chronic renal failure receiving amiodarone for the treatment of refractory arrhythmias were commenced on dialysis, in one case, intermittent peritoneal dialysis, in the other, haemodialysis. Plasma concentrations of amiodarone and its desethyl metabolite were consistent with the dose received, whilst neither compound was recovered in the dialysate. In these patients and in $\mathbf{1 0}$ additional patients with normal renal function taking amiodarone, only negligible amounts of either compound were detected in urine. These findings suggest that amiodarone may be a suitable antiarrhythmic agent for use in patients with chronic renal failure.
\end{abstract}

KEY WORDS: amiodarone, renal elimination, peritoneal dialysis, haemodialysis.

\section{Introduction}

The antiarrhythmic agent amiodarone is a benzofuran derivative (mol.wt. 680) with a long duration of action. Recently, a desethyl metabolite has been noted in the plasma of patients receiving the drug (Flanagan et al., 1982). Little is known about the elimination of amiodarone although work by Broekhuysen suggested that hepatic rather than renal clearance was the major route of excretion (Broek-

\footnotetext{
* Present address: Sunnybrook Hospital, University of Toronto Clinic, 2075 Bay View Avenue, Toronto, Ontario, Canada.

Correspondence to D. W. Holt.
}

huysen, Laruel and Sion, 1969). A patient with polycystic kidneys who was taking amiodarone fer control of atrial fibrillation, required intermftent peritoneal dialysis and we took the opportunity to measure this drug and its metabolite in plasma, efroe and dialysate. Similarly, a second patient wwh chronic renal failure was treated by haemodialysis whilst receiving amiodarone and the two compourns were measured in plasma before and after dialysis, and samples of dialysate were analysed for their presence. The concentrations of these compounds $\exists$ n urine were compared with those from patients with normal or mildly impaired renal function who we also receiving amiodarone.

\section{Patients and methods}

Case 1

A 58-year-old male with a prosthetic mitral vaßve was admitted in atrial fibrillation and cardiac failufe. The atrial fibrillation proved refractory to conve tional antiarrhythmic agents but the rapid ventricukgr rate was controlled with amiodarone, $800 \mathrm{mg}$ dailby for 1 week and $200 \mathrm{mg}$ daily thereafter. In addition, the patient was known to have polycystic kidneys afid there had been a progressive deterioration in renal function (urea-60.4 mmol/litre, creatinine- 691 $\mu \mathrm{mol} / \mathrm{litre})$. Intermittent peritoneal dialysis ( 2 houg $\mathrm{g}$ cycles of 2 litres dialysate, $48 \mathrm{hr}$ per week) was commenced 4 months later. Blood samples we fe collected before, during and after $48 \mathrm{hr}$ of peritongal 
TABle: I. Chronic peritoneal dialysis. Patient receiving $200 \mathrm{mg}$ amiodarone daily. Measurements made 8 hr post-dose. (Data for 58 -year-old male patient)

\begin{tabular}{|c|c|c|c|c|c|c|}
\hline & \multicolumn{2}{|c|}{ Plasma } & \multicolumn{2}{|c|}{ Dialysate } & \multicolumn{2}{|c|}{ Urine } \\
\hline & $\begin{array}{c}\text { Amiodarone } \\
(\mathrm{mg} / \text { litre })\end{array}$ & $\begin{array}{l}\text { Desethyl- } \\
\text { amiodarone } \\
\text { (mg/litre) }\end{array}$ & $\begin{array}{c}\text { Amiodarone } \\
\text { (mg/litre) }\end{array}$ & $\begin{array}{l}\text { Desethyl- } \\
\text { amiodarone } \\
\text { (mg/litre) }\end{array}$ & $\begin{array}{c}\text { Amiodarone } \\
\text { (mg/litre) }\end{array}$ & $\begin{array}{l}\text { Desethyl- } \\
\text { amiodarone } \\
\text { (mg/litre) }\end{array}$ \\
\hline $24 \mathrm{hr}$ after dialysis commenced & 0.5 & 0.6 & ND & ND & - & - \\
\hline $48 \mathrm{hr}$ after dialysis commenced & 0.4 & 0.5 & ND & ND & - & - \\
\hline $24 \mathrm{hr}$ post-dialysis & 0.5 & $0 \cdot 5$ & - & - & $0 \cdot 02$ & $0 \cdot 13$ \\
\hline 4 days post-dialysis & $0 \cdot 6$ & 0.7 & - & - & 0.02 & $0 \cdot 14$ \\
\hline
\end{tabular}

$\mathrm{ND}=$ not detected. Lower limit of detection $=0.005 \mathrm{mg} / \mathrm{l}$.

dialysis, together with samples of dialysate and urine for the measurement of amiodarone and desethylamiodarone.

\section{Case 2}

A 54-year-old anuric woman with chronic renal failure secondary to membranous nephropathy, treated by haemodialysis, received amiodarone, 400 mg daily, for the treatment of symptomatic ventricular tachycardia. One month after starting amiodarone therapy, blood samples were collected before and after dialysis on 3 occasions (19 and $24 \mathrm{hr}$ after amiodarone) together with samples of dialysate, for the measurement of amiodarone and desethylamiodarone.

In addition, samples of blood and urine were collected from 10 patients ( 8 male, mean age ( \pm s.d.) $54( \pm 10 \cdot 2)$ years) receiving chronic amiodarone therapy, mean daily dose ( \pm s.d.) $359( \pm 235) \mathrm{mg}$. In all cases, the samples were collected 8-12 hr after the last dose had been administered. In 9 of these patients, the serum creatinine was within the normal limits for our laboratory whilst one patient had a modestly elevated serum creatinine of $157 \mu \mathrm{mol} /$ litre.

Plasma amiodarone and desethylamiodarone were measured using a specific high-performance liquid chromatographic technique (Flanagan, Storey and Holt, 1980). At the increased sensitivity required for the measurement of these compounds in dialysis fluid and urine, a modification of this method was employed (Storey and Holt, 1982).

\section{Results}

In Case 1, plasma concentrations of amiodarone and its metabolite were well within the range for the dose prescribed (Holt and Storey, 1983) (Table 1) and these did not fluctuate significantly during dialysis. Neither the parent compound nor the metabolite were detected in the dialysate, and only minimal quantities of these compounds were measured in urine.
In case 2 , there was little fluctuation in mean plasma amiodarone and desethylamiodarone concentrations between pre-dialysis $(1 \cdot 19 \pm 0.31$, $1.03 \pm 0.02 \mathrm{mg} /$ litre) and post-dialysis (1.00 \pm 0.11 , $0.97 \pm 0.04 \mathrm{mg} /$ litre) samples, respectively. Neither compound could be detected in dialysate (limit of detection $0.005 \mathrm{mg} /$ litre).

In the 10 additional patients receiving chronic amiodarone therapy, the mean urinary concentration of amiodarone was $0.029 \pm 0.027 \mathrm{mg} /$ litre and for desethylamiodarone was $0 \cdot 149 \pm 0.132 \mathrm{mg} / \mathrm{litre}$; mean plasma concentrations were $2.08 \pm 1.47$ $\mathrm{mg} /$ litre (amiodarone) and $1.48 \pm 0.90 \mathrm{mg} /$ litre(desethylamiodarone). No correlation was found between urinary excretion of these compounds and serum creatinine or amiodarone dosage.

\section{Discussion}

Amiodarone is a class III antiarrhythmic agent, effective in the management of atrial and ventricular arrhythmias. However, its clinical use has been limited by its association with a number of unwanted effects ranging from asymptomatic corneal deposits, detectable only on slit lamp examination (Verin et al., 1971), to clinical thyroid dysfunction with both hypoand hyper-thyroidism being described (Wolff, 1969; Savoie et al., 1975; Jaggarao et al., 1982). More recently, amiodarone has been implicated as a possible cause of pulmonary fibrosis (Rotmensch et al., 1980; Heger et al., 1981). Notwithstanding these unwanted effects, amiodarone has proved sufficiently valuable in the management of refractory arrhythmias that its use in clinical practice is often required.

Despite its introduction 20 years ago, initially as an anti-anginal agent (Vastesaeger, Gillot and Rasson, 1967), data on the pharmacokinetics of amiodarone have appeared only recently, following the development of a method to measure amiodarone and its desethyl metabolite in plasma. Both compounds have a long terminal half-life of elimination (of the order of 50 days), amiodarone having a comparatively low clearance and large volume of distribution (Holt and Storey, 1983). On a chronic oral daily dose of $400 \mathrm{mg}$ 
amiodarone, patients achieve a mean plasma concentration of $2 \cdot 12 \pm 0.80 \mathrm{mg} /$ litre (amiodarone) and $1.94 \pm 0.56 \mathrm{mg} /$ litre (desethylamiodarone); the ratio parent compound/metabolite is approximately one (Holt and Storey, 1983). To date, desethylamiodarone is the only metabolite identified in biological fluids and tissues; its pharmacological activity in not known and the methodology employed in this study does not exclude the possibility of other, more water soluble, metabolites.

Salivary measurements of amiodarone suggest that the drug is highly protein bound (of the order of $98 \%$ ) (Holt and Storey, unpublished observation) and displacement of other highly protein-bound drugs by amiodarone could be clinically important, although the marked potentiation of the action of warfarin by amiodarone is unlikely to be due to this mechanism (Serlin, Sibeon and Green, 1981).

Earlier work by Broekhuysen et al. (1969), using ${ }^{131}$ I-labelled amiodarone suggested that the main route of elimination of the drug was via the gastrointestinal tract with little being excreted in urine. Consistent with these data, very low concentrations of parent compound and metabolite were measured in the urine of our 10 subjects with normal or mildly impaired renal function. Similarly, negligible amounts of these compounds were found in the urine of one of our patients with chronic renal failure suggesting that the renal route is not significant in the elimination of the drug. Nor were the compounds detectable in dialysis fluid, probably reflecting their very large volume of distribution and poor aqueous solubility.

In addition, our patients with chronic renal failure had plasma amiodarone and desethylamiodarone concentrations well within the normal range for the dose administered and duration of therapy, and there were minimal fluctuations between dialysis. These concentrations, coupled with a ratio of parent compound/metabolite in the range $0 \cdot 8-1 \cdot 2$, suggest that biotransformation of amiodarone is not altered significantly in renal failure and that no dosage adjustment will be required in these patients. This would represent a definite advantage over many other antiarrhythmic agents such as digoxin, disopyramide and procainamide which are largely eliminated by the kidney (Woosley and Shand, 1978). With these latter drugs, dosage adjustment and careful monitaring of drug plasma levels are essential in renal failưe if toxicity is to be avoided.

\section{References}

BRoekhuYSEN, J., LARUEL, R. \& SION, R. (1969) Recherches dons la serie des benzofurannes XXXVII. Etude comparee du transifet du metabolisme de l'amiodarone chez diverses especes animale్f.et chez l'homme. Archives Internationales de Pharmacodynamie etde Therapie, 177, 340.

Flanagan, R.J., Storey, G.C.A. \& Holt, D.W. (1980) Ragid high-performance liquid chromatographic method for the rficasurement of amiodarone in blood plasma or serum at the concentrations attained during therapy. Journal of Chromatography, 187, 391.

Flanagan, R.J., STORey, G.C.A., Holt, D.W. \& Farmer, (1982) Identification and measurement of desethylamiodaronoin blood plasma specimens from amiodarone-treated patients. nal of Pharmacy and Pharmacology, 34, 638.

Heger, J.J., Prystowsky, E.N., Jackman, W.M., Naccareïin, G.V., WARFEL, K.A., RINKENBERGER, R.L. \& ZIPES, D.P. (1981) Amiodarone: clinical efficacy and electrophysiology during term therapy for recurrent ventricular tachycardia or ventrictular fibrillation. New England Journal of Medicine, 305, 539.

HolT, D.W. \& STOREY, G.C.A. (1983) Measurement of amioderone. In: Amiodarone and arrhythmias (Eds. D.M. Krikler, IDA. Chamberlain and W.J. McKenna), p. 11. Pergamon Press, Oxford.

JaGgarao, N.S.V., Sheldon, J., GRUNDY, E.N., VinCENT, R \& Chamberlain, D.A. (1982) The effects of amiodarone on thy function. Postgraduate Medical Journal, 58, 693.

ROTMENSCH, H.H., LIRON, M., TUPILSKI, M. \& LANIADO, S. (1980) Possible association of pneumonitis with amiodarone thrapy. American Heart Journal, 100, 412.

Savoie, J.C., Massin, P., Thomopoulos, P. \& Leger, F. A.gण) Iodine-induced thyrotoxicosis in apparently normal glands. Journal of Clinical Endocrinology and Metabolism, 4T, 5 .

SERlin, M.J., SibEON, R.G. \& GREEN, G.J. (1981) Dangersōf amiodarone and anticoagulant treatment. British Medical Jourfal, 283, 58.

STOREY, G.C.A. \& HoLT, D.W. (1982) High-performance liquid chromatographic measurement of amiodarone and desethylariodarone in plasma or serum at the concentration attained following a single $400 \mathrm{mg}$ dose. Journal of Chromatography, 245, 377.

VASTESAEGER, M., GILlot, P. \& RASSON, G. (1967) Etude cling d'une nouvelle medication anti-angoreuse, Acta Cardiologica (Bruxelles), 22, 483.

Verin, P., Gendre, P., BarcheWITZ, G., LAURENT-Bronch G., YACOUBI, M. \& MORAX, S. (1971) Thes aurismose corneeime par amiodarone: donnees recentes. Archives of Opthalmology 31 , 581.

WOLFF, J. (1969) lodide goitre and the pharmacologic effect? excess iodide. American Journal of Medicine, 47, 101.

WoOSLEY, R.L. \& SHAND, D.G. (1978) Pharmacokinetics of a@iarrhythmic drugs. American Journal of Cardiology, 41, 986.

(Accepted 27 January 1983) 